\title{
PrP systemic amyloidosis
}

INSERM

\section{Source}

INSERM. (1999). Orphanet: an online rare disease and orphan drug data base. PrP systemic amyloidosis. ORPHA:397606

Prion protein (PrP) systemic amyloidosis, previously known as chronic diarrhea with hereditary sensory and autonomic neuropathy is an extremely rare autosomal dominant disorder reported in three British families, a Japanese and an Italian family (about 16 cases in total). Onset is usually in the fourth decade of life and the course lasts about 20 years. Reported clinical manifestations include diarrhea, nausea, autonomic failure (areflexia, weakness), neurogenic bladder and urinary infections. The disorder is caused by truncation mutations of the prion protein gene PRNP (20p13) leading to deposition of prion protein amyloid. 